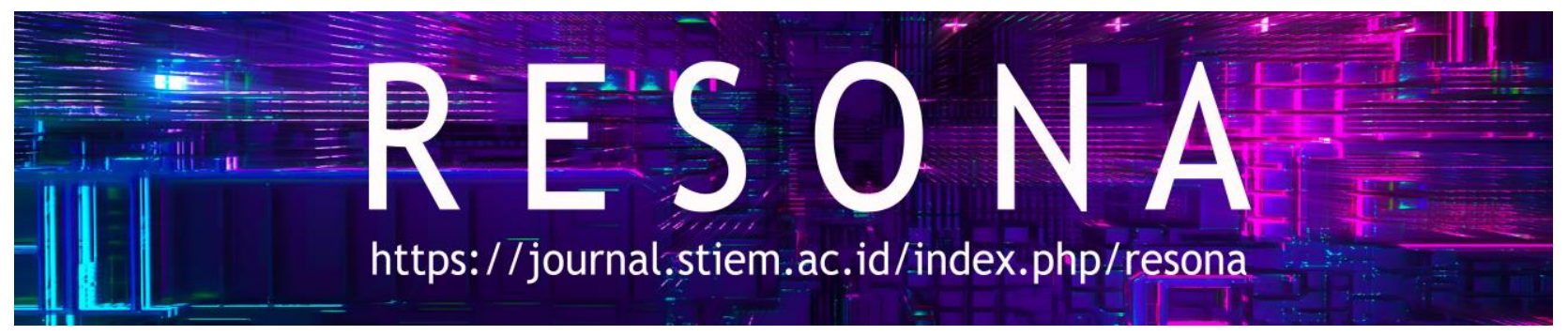

\title{
Penyuluhan Perencanaan Keuangan Keluarga Islami Warga RT Kuncen Sukoharjo
}

Muhammad Hanif Al-Hakim ${ }^{1}$, Azhar Alam², Ade Indra ${ }^{3}$

${ }^{1,2,3}$ Universitas Muhammadiyah Surakarta

\begin{tabular}{l} 
INFO NASKAH \\
\hline Diserahkan 23 September 201 \\
Diterima \\
30 September 2019 \\
Diterima dan Disetujui 15 \\
Desember 2019 \\
Kata Kunci: Penyuluhan, \\
keuangan, keluarga, islami \\
Key Words: \\
Counseling, Finance, Family, \\
Islamic
\end{tabular}

\section{INFO NASKAH}

\section{Diterima}

30 September 2019

Desember 2019

Kata Kunci: Penyuluhan,

Key Words:

Islamic

\section{ABSTRAK}

Para anggota Pemberdayaan dan Kesejahteraan Keluarga (PKK) di daerah Kuncen Sukoharjo belum memiliki pengetahuan tentang urgensi perencanaan keuangan keluarga, padahal wawasan tersebut penting untuk dipahami terutama oleh ibu-ibu sebagai pemegang kas rumah tangga. Tujuan kegiatan pengabdian kepada masyarakat ini adalah: (1) Menimbulkan kesadaran dan mengubah persepsi umum tentang perencanaan keuangan keluarga (2) Menambah wawasan masyarakat tentang penerapan ilmu pembukuan sederhana untuk pengaturan sebuah keluarga. Metode untuk memenuhi tujuan tersebut adalah ceramah dan dialog interaktif. Hasil yang dicapai dalam kegiatan pengabdian masyarakat ini: (1) Timbulnya kesadaran anggota PKK RT 1 RW 12 tentang pentingnya pengetahuan akan perencanaan keuangan keluarga, dan (2) Anggota PKK RT 1 RW 12 dapat mempraktekkan pengetahuan yang akan didapatkan lewat penyuluhan ini dalam lingkungan rumah tangga mereka masing-masing.

Abstrack. Members of Empowerment and Family Welfare (PKK) in the Kuncen Sukoharjo area did not yet know the urgency of family financial planning, even though this insight was essential to understand, especially by mothers as household cash holders. The objectives of community service activities were (1) Raising awareness and changing general perceptions about family financial planning (2) Adding public insight into the application of pure bookkeeping knowledge to the management of a family. The methods for meeting these objectives were lectures and interactive dialogue. There were two results from this community service activity; they were (1) Awareness of PKK RT 1 RW 12 members about the importance of knowledge about family financial planning. (2) PKK RT 1 RW 12 members can practice the knowledge that will be obtained through this counseling in the home environment in their respective steps. 


\section{Pendahuluan}

Globalisasi informasi memudahkan warga yang hidup di zaman ini dalam mencari dan membeli kebutuhan mereka sehari-hari. Bahkan barang-barang yang tidak mendesak untuk dibeli pun secara sadar terbeli, meskipun dengan perasaan menyesal di akhir. Hal ini disebabkan kemudahan transaksi jual-belinya dan iklan-iklan yang begitu menggoda calon pembeli. Mengingat fenomena ini maka perencanaan keuangan merupakan satu ketrampilan yang harus dimiliki bagi mereka yang hidup pada abad 21 ini, baik untuk pribadi, keluarga, maupun sebuah organisasi.

Perencanaan keuangan, khususnya untuk keluarga, menjadi bagian penting dalam manajemen rumah tangga (tadbir al-manzil) seorang muslim. Namun, berdasarkan data Otoritas Jasa Keuangan (OJK), di Indonesia yang mayoritas warganya Muslim, hanya 12,6 persen yang tercatat telah melakukan perencanaan keuangan (www.cnnindonesia.com, 2017). Selebihnya menganggap bahwa masalah rezeki sudah digariskan Allah sehingga tidak perlu direncanakan atau diprogram segala rupa (Tamanni and Mukhlisin, 2013). Bagi orang awam pernyataan itu cukup masuk akal, tapi akan lebih baik jika seorang Muslim berikhtiar membuat perencanaan keuangannya agar menjaga mereka dari terjerumus membelanjakan harta untuk sesuatu yang tidak bermakna atau mubazir. Selain mempertimbangkan tujuan syariah tersebut, telah dibuktikan juga bahwa pengaruh kesadaran akan perencanaan keuangan berbanding lurus dengan kesejahteraan keluarga terkait (Wulandari, 2014).

Anggota gerakan Pemberdayaan dan Kesejahteraan Keluarga (PKK) RT 1 RW 2, Mahamhaji Kartasura merupakan ibu-ibu rumah tangga RT Kuncen. Mereka secara rutin dan disiplin telah lama menjalankan program-program kerja organisasi tersebut. Beberapa program yang sudah dijalankan lebih cenderung bertujuan untuk meningkatkan ketrampilan tataboga anggotanya, dan penanaman kesadaran akan kesehatan lingkungan.

Ketersediaan para pengisi pengajian atau pembicara dalam program masih terbatas pada kajian akhlak dan belum pernah ada yang berusaha menyentuh pentingnya perencanaan keuangan keluarga, padahal hal tersebut merupakan salah satu praktek terapan salah satu maqashid syariah yang lima, yaitu hifzul-mal (menjaga harta). Sebanyak 15\% profesi anggota PKK adalah pegawai yang bekerja di luar kampung (baik swasta atau PNS), sedangkan selebihnya didominasi oleh ibu-ibu yang bekerja sehari-hari sebagai ibu rumah tangga.

Perlu untuk diketahui bahwa salah satu penyebab ibu-ibu tersebut merasa nyaman menjadi ibu rumah tangga adalah karena mereka dahulunya tidak mengeyam pendidikan di bangku kuliah sehingga menjadi pertimbangan pihak yang ingin mempekerjakan mereka juga. Bahkan sebagian 
besar dari mereka juga tidak lulus pendidikan sekolah menengah, sehingga kami sebagai pengaju program ini tidak bisa berekspektasi tinggi akan tingkat financial literacy (literasi keuangan) mereka.

\section{Masalah}

Beberapa permasalahan yang ingin dipecahkan dengan diadakannya program pengabdian ini adalah:

1. Bagaimana menambah pengetahuan ke masyarakat tentang batasan hak dan kewajiban penggunaan harta.

2. Bagaimana menaikkan kesejahteraan masyarakat setelah mereka mengetahui ilmu tentang batasan hak dan kewajibabn penggunaan harta.

3. Bagaimana menggugah kesadaran masyarakat tentang pengelolaan harta seperti yang terdapat dalam Qur'an dan Sunnah.

\section{Metode}

Materi dalam program PKK selama ini cenderung lebih banyak porsinya kepada penyuluhan yang berkaitan tataboga dan kesehatan. Dilihat dari satu sisi, tidak ada salahnya mengisi program dengan materi semacam itu. Namun disini tidak pernah disampaikan materi tentang perencanaan keuangan keluarga Islami, baik itu karena tiada kesadaran anggota tentang hal tersebut, atau mungkin jikapun mereka sadar, tidak adanya penyuluh agama yang coba mengkaitkan dalil zahir tentang harta dengan isu pentingnya perencanaan keuangan keluarga. Berangkat dari kondisi ini maka, dibutuhkan rencana kegiatan pengabdian masyarakat dengan tema pengabdian "Penyuluhan Perencanaan Keuangan Keluarga Islami Di Kuncen RT 1/12, Makamhaji, Kartasura, Sukoharjo."

Agenda ini mengambil tempat di rumah salah satu warga RT 1 RW 12 tepat ketika acara rutin PKK pada hari Ahad sore bakda shalat Asar hingga menjelang Maghrib. Acara akan berlangsung selama kurang lebih 2 jam, dengan estimasi 90 menit pemaparan materi, 15 menit dialog interaktif, dan 15 menit praktek aplikasi materi. Progam ini memakai metode ceramah, dialog interaktif dengan memberi kesempatan peserta untuk memberikan pertanyaan lewat tulisan ataupun pesan pertanyaan yang ditujukan kepada panitia penyelenggara, dan partisipasi aktif dari masing-masing peserta. 


\section{Hasil dan Pembahasan}

\section{Tempat dan Waktu Pelaksanaan}

Kegiatan pengabdian masyarakat ini bertempat di Masjid at-Taqwa, Kuncen RT 1/12 Kelurahan Makamhaji, Kecamatan Kartasura, Sukoharjo, Jawa Tengah. Pelaksanaan penyuluhan dilakukan pada hari Ahad sore, 3 Maret 2019. Acara berlangsung selama 2 jam, dengan alokasi 90 menit pemaparan materi, 15 menit dialog interaktif, dan 15 menit praktek aplikasi materi. Berikut beberapa foto dokumentasi pelaksanaan kegiatan pengabdian masyarakat:

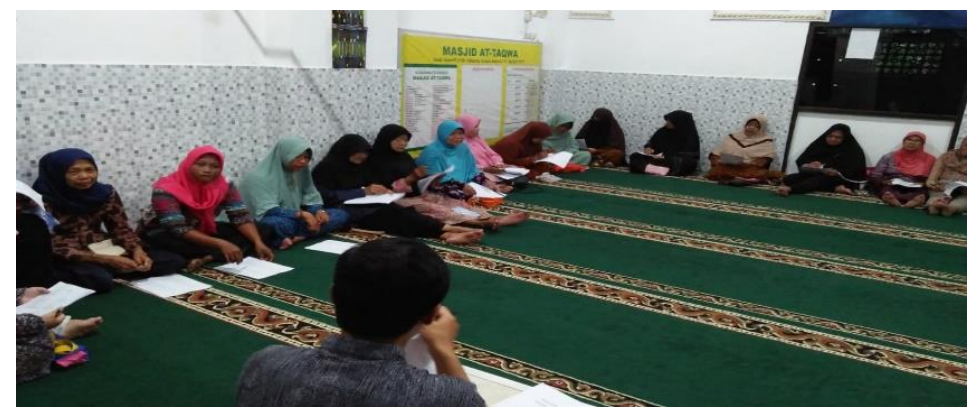

Gambar 1 Dokumentasi Kegiatan Penyampaian Materi Pengabdian

Kegiatan pengabdian masyarakat yang mengambil tema Penyuluhan Perencanaan Keuangan Keluarga Islami ini diikuti oleh ibu-ibu yang tergabung dalam anggota Pemberdayaan dan Kesejahteraan (PKK) Kuncen RT 1 RW 12. Peserta terbagi kedalam tujuh kelompok, dengan nomenklatur Dasa Wisma (DaWis). Tiap Dawis beranggotakan sepuluhanggota. Dalam pelaksanaannya, empat Dawis berada di posisi sebelah kanan Masjid, sedangkan tiga Dawis lainnya berada di sebelah kiri.

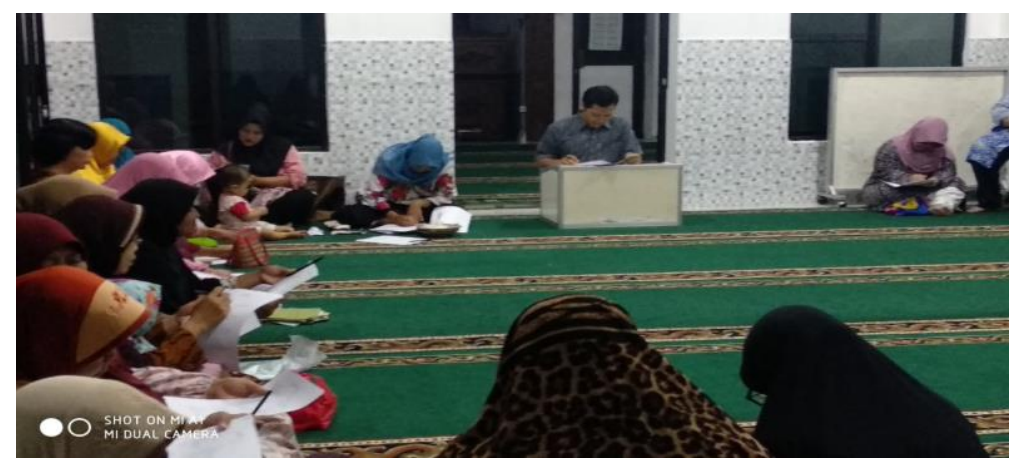

Gambar 2 Peserta tiga Dawis yang berada di sebelah kiri Masjid

Gambar 1 dan 2 menunjukkan suasana kegiatan pengabdian masyarakat dengan progam Penyuluhan Perencanaan Keuangan Keluarga Islami ini. 


\section{Pemahaman Peserta Terhadap Perencanaan Keuangan Keluarga}

Dalam bagian ini akan dipaparkan pemahaman dan pengetahuan para peserta tentang pentingnya perencanaan keuangan keluarga. Total peserta yang menghadiri kegiatan penyuluhan ini berjumlah 46 orang, kurang lebih 2/3 dari total anggota keseluruhan 70 orang. Usia peserta berada dalam rentang 28 - 70 tahun. Dari 46 jumlah kuisioner yang dibagikan, hanya 39 kuisioner yang dikembalikan. Mengingat angka 39 sudah melebihi setengah dari angka 70 total anggota PKK, maka ia sudah dianggap mewakili, dan atas dasar itulah deskripsi tentang subbab ini ditulis.

\section{Persepsi Peserta Tentang Ke-syamil-an Islam}

Beberapa informasi yang dapat disimpulkan dari kuesioner yang telah dikumpulkan adalah, diantara, bahwa seluruh peserta telah menyadari bahwa keuangan keluarga perlu direncanakan (lihat soal No. 2), walaupun tidak semua dari mereka benar-benar telah melakukannya. Terlihat dalam tabel di bawah ini, bahwa masih terdapat tiga orang yang belum pernah sama sekali merencanakan keuangan keluarganya.

Hal itu tentu dapat dipahami, mengingat ada juga peserta, berjumlah tujuh orang, yang menganggap bahwa ibadah itu hanya terbatas pada sholat, puasa, zakat dan naik haji, dengan kata lain, ibadah yang tergabung dalam lima rukun Islam (soal No. 3). Ini juga dikuatkan dengan masih adanya persepsi bahwa Islam tidak mengatur hal-hal yang berkaitan dengan kekayaan keluarga dan anggapan bahwa perencanaan keuangan keluarga bukanlah salah satu bentuk ibadah (soal No. 4 dan 5). Selain dari itu, alasan lain yang mungkin bisa menjelaskan kenapa ada peserta yang sama sekali tidak pernah merencanakan keuangan keluarga adalah masalah keterbatasan wawasan dan ketrampilan peserta tentang perencanaan keuangan keluarga. 


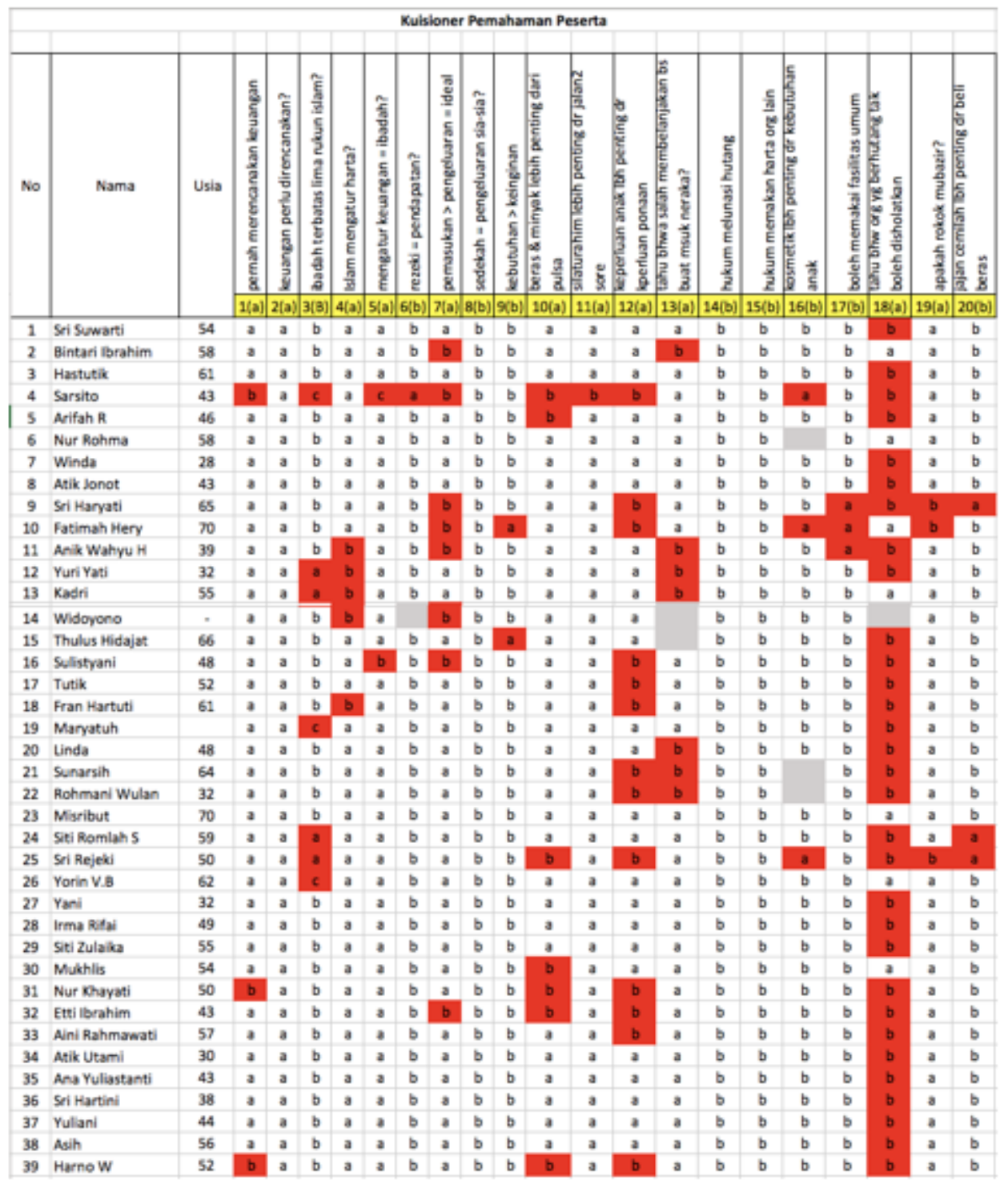

Gambar 3. Hasil Kuesioner Kegiatan Penyuluhan Perencanaan Keuangan

\section{Persepsi Peserta Tentang Hukum-Hukum Terkait Harta}

Informasi lain yang dapat diketahui dari hasil kuesioner yang telah diolah adalah persepsi para responden tentang hukum-hukum terkait kekayaan keluarga. Poin ini perlu mendapat perhatian lebih karena ia termasuk salah satu pilar dalam perencanaan keuangan Islami, baik di level pribadi dan keluarga. Hal ini karena adanya hadis Nabi Muhammad SAW yang menerangkan bahwasanya isu harta kekayaan termasuk salah satu perihal yang harus dipertanggungjawabkan kelak di Akhirat, dan itu mencakup masalah darimana harta itu didapatkan dan untuk apa harta itu disalurkan.

Oleh karena itu, mengetahui hukum-hukum terkait harta menjadi penting. Di tahap awal kegiatan pengabdian, peserta diharapkan sudah mengetahui bahwa hukum-hukum 
seperti wajib, sunah, mubah, dan haram juga ternyata terkena juga keatas perbuatan hamba yang berkaitan dengan harta. Namun, hasil kuisioner menunjukkan kenyataan bahwa para peserta tidak faham secara penuh tentang hukum-hukum tersebut.

Salah satu indikator yang menunjukkan gejala tersebut terlihat pada jawaban para peserta terhadap soal nomor 13 tentang apakah mereka tahu bahwa salah dalam membelanjakan harta bisa menyebabkan manusia masuk neraka. Tujuh orang merespon dengan jawaban 'tidak tahu', sedangkan dua anggota tidak memberikan jawaban. Jawaban tersebut merupakan sinyal bahwa para mereka tidak mempunyai pengetahuan tentang adanya hukum yang lima (wajib, sunnah, mubah, makruh, haram) yang berkaitan dengan aktivitas manusia yang melibatkan harta. Bahkan lebih konkrit lagi, ketika dihadapkan pertanyaan apakah merokok termasuk perbuatan mubazir, ada tiga anggota yang menjawab 'tidak'. Padahal seperti yang sudah diketahui bersama bahwa Majelis Ulama Indonesia (MUI) telah berfatwa bahwa rokok itu haram, maka membeli rokok tergolong aktivitas yang sia-sia, oleh sebab itu disebut mubazir.

\section{Persepsi Peserta Tentang Peringkat Pengeluaran}

Islam telah mengatur prioritas terkait alokasi pembelanjaan harta. Dalam kitab alKasb, Imam Muhammad bin al-Hasan al-Shaybani, (w.189.H) telah menjelaskan bahwa pendapatan seseorang seyogyanya dibelanjakan berdasarkan prioritas yang telah diatur oleh Islam berdasarkan prioritas urutannya, yaitu 1) untuk kebutuhan sandang, pangan, dan papan; 2) untuk membayar hutang; 3) untuk membiayai keperluan anggota keluarga / istri dan anak; 4) untuk merawat orangtua yang sudah renta; 5) untuk keperluan silaturahim antar kerabat dekat (Al-Shaybani, 2005).

Melalui kuisioner yang telah dirancang sedemikian rupa, telah diketahui bahwasanya ada beberapa peserta kegiatan penyuluhan yang belum sama sekali tahu adanya lima peringkat pengeluaran tersebut. Hal itu tercermin dari jawaban peserta ketika mereka dihadapkan dengan pertanyaan nomor $9,10,11,12,16$, dan 20 yang mana soal-soal tersebut memang dibuat demi menggali tingkat pemahaman para peserta tentang prioritas pembelanjaan harta. Misalnya, pertanyaan nomor 9, yang dapat dikatakan sebagai soal yang sangat sederhana, menggali persepsi peserta tentang mana yang seharusnya didahulukan, keinginan atau kebutuhan. Dua peserta menjawab bahwa keinginan harus didahulukan ketimbang kebutuhan. 
Selanjutnya, terkait dengan soal nomor 10 yang menggali persepsi peserta tentang apakah beras dan minyak goreng lebih penting daripada pulsa, ada tujuh orang yang lebih mengutamakan pulsa ketimbang beras dan minyak goreng. Ini menunjukkan bahwa beberapa dari peserta lebih mementingkan pulsa yang notabenenya kebutuhan tersier daripada beras dan minyak goreng yang bisa dianggap sebagai kebutuhan primer, karena kedua-duanya termasuk kebutuhan pangan, yang mana tanpa keduanya keberlangsungan hidup para peserta sebagai manusia biasa akan terganggu.

Keawaman para peserta penyuluhan juga tampak ketika mereka merespon kuesioner khususnya di pertanyaan nomor 12 , dimana mereka diberikan soal tentang pilihan apakah jajan untuk anak sendiri ataukah jajan untuk keponakan yang harus lebih dipentingkan. Sejumlah tiga belas orang menjawab bahwa memberi uang untuk jajan kepada keponakan itu lebih utama daripada memberi uang untuk jajan kepada anak sendiri. Ini menunjukkan fakta adanya kebingungan tentang urutan prioritas pengeluaran harta antara prioritas nomor tiga dan nomor lima.

\section{Dialog Interaktif Antara Pemateri dan Peserta}

Rentetan acara setelah penyampaian materi adalah dialog antar pemateri dan peserta penyuluhan dalam bentuk sesi tanya jawab. Seorang ibu yang bernama Ibu Dayah mengajukan dua pertanyaan, yang kemudian menjapat respon jawaban dari pemateri: Pertanyaan: Bagaimana hukumnya apabila sebuah bank komersil menyita seluruh aset-aset properti seorang nasabah kredit, dalam keadaan hutangnya belum lunas, setelah ia meninggal dunia?

Jawaban: Dalam hal ini, seharusnya pihak bank menaksir terlebih dahulu total nilai aset-aset nasabah tadi, lalu setelah itu barulah aset-aset tersebut dilelang. Uang hasil penjualan aset-set tersebut kemudian akan dibayarkan untuk menebus sisa hutang si nasabah. Jika ternyata ada sisa uang setelah penebusan hutang nasabah tadi, maka pihak bank harus menyerahkan sisa uang itu kepada keluarga kerabat almarhum. Sebaliknya, jika ternyata hasil penjualan aset tidak menutupi total hutang almarhum, maka pihak keluarga harus menambal sisa hutang almarhum. Namun kenyataan di lapangan tidak demikian. Oleh karena itu, marilah kita jangan terlalu mudah dalam memiliki hutang.

Pertanyaan: Saya seorang pensiunan tenaga pendidik. Ketika habis masa bakti saya dulu, saya meninggalkan hutang kepada koperasi yang sampai sekarang cicilannya dibayarkan dari gaji pensiunan saya. Sisa cicilan saya sampai sekarang masih berjalan 
sampai satu setengah tahun kedepan. Nah, kebetulan dalam waktu yang bersamaan, saya mempunyai TV, dan keadaannya sedang rusak. Pertanyaannya, bolehkah saya menunda membayar cicilan koperasi dengan alasan uangnya akan saya gunakan untuk memperbaiki TV yang rusak tadi?

Jawaban: Membayar hutang adalah prioritas urutan nomor dua, sedangkan TV bukanlah kebutuhan primer, yang tanpanya pun ibu masih bisa hidup dengan nyaman. Oleh sebab itu, ibu tidak boleh menunda cicilan koperasi tadi.

\section{Simpulan dan Saran}

Sel yang diblok warna merah dalam hasil kuesioner diatas menunjukkan jawaban yang tidak tepat dari peserta terhadap pertanyaan yang diajukan, padahal tingkat kerumitan dan kesulitan dari soal-soal tersebut bisa dibilang rendah. Terlebih lagi, masa kuisioner diisi adalah selama waktu penyampaian materi, yang berarti bahwa peserta sebenarnya telah mendapatkan jawaban-jawaban kuesioner itu dalam materi yang disampaikan, namun masih saja ada yang menjawab dengan tidak benar. Hal ini membuktikan bahwa materi tentang perencanaan keuangan ini termasuk rumit apalagi untuk kalangan awam di desa, karena ia merupakan terapan dua disiplin ilmu, yaitu Syariah dan Ekonomi.

Saran yang dapat diberikan oleh tim kegiatan penyuluhan ini diantaranya adalah bahwa mengingat pentingnya topik perencanaan keuangan keluarga Islami ini dan mengingat sulitnya mencerna materi yang, walaupun menurut para civitas akademik termasuk sederhana, merupakan gabungan dua disiplin ilmu seperti yang disebutkan di paragraf sebelumnya di atas, maka kegiatan seperti ini harus tetap diadakan di kesempatan lain kedepannya dengan persiapan materi yang lebih simplenamun tetap substansif, sehingga bisa diikuti oleh para anggota PKK dan diamalkan sehari- hari.

\section{Ucapan Terima Kasih}

Kegiatan pengabdian pada masyarakat ini tidak dapat terlaksana dengan lancar dan berhasil tanpa bantuan dan dukungan dari berbagai pihak terkait. Dengan selesainya kegiatan ini, kami mengucapkan terima kasih kepada:

1. Rektor universitas Muhammadiyah Surakarta yang telah memberikan izin dan fasilitas untuk pengabdian ini

2. Ketua Lembaga Penelitian dan Pengabdian pada Masyarakat UMS yang telah memberikan dorongan dan bimbingan untuk melakukan kegiatan ini. 
3. Ketua PKK Kuncen RT 01/12 yang telah memberikan izin untuk melaksanakan kegiatan ini.

\section{Daftar Pustaka}

Al-Shaybani, M. ibn al-H. (2005) Kitab al-Kasb. Beirut: Dar al-Bashair al-Islamiyyah.

Tamanni, L. and Mukhlisin, M. (2013) Sakinah Finance: Solusi Mudah Mengatur Keuangan Keluarga Islami. Solo: Tinta Medina.

Wulandari, F. A. (2014) 'Pengaruh Tingkat Kesadaran Masyarakat Dalam Perencanaan Keuangan Keluarga Terhadap Kesejahteraan', Jurnal Siasat Bisnis, 18(1), pp. 21-31.

www.cnnindonesia.com (2017) Hanya-126-persen-masyarakat-indonesia-punya-rencanakeuangan. 